\section{KẾT LUẬN}

Trong báo cáo ca bệnh này, lần đầu tiên chúng tôi đã tiến hành điều trị bằng liệu pháp miễn dịch tự thân $\gamma \delta T$ trên bệnh nhân ung thư phổi không tế bào nhỏ. Kết quả lâm sàng, cận lâm sàng và chẩn đoán hình ảnh đã cho thấy liệu pháp tế bào miễn dịch tự thân là an toàn và mang lại hiệu quả khả quan trên bệnh nhân ung thư phổi. Hy vọng rằng, thử nghiệm này sẽ mở ra bước tiến mới trong nghiên cứu và điều trị ung thư sử dụng liệu pháp tế bào miễn dịch tự thân và truyền cảm hứng nhiều hơn cho các nghiên cứu thử nghiệm lâm sàng trong tương lai.

Lời cám ơn. Kết quả nghiên cứu này thuộc đề tài cấp nhà nước "Nghiên cứu sử dung tế bà̀ miễn dịch tự thân gamma delta $T(\gamma \delta \bar{T})$ và diệt tự nhiến (NK) trong điều trị ung thư phổi" do trường Đại học Y Hà Nội chủ trì, PGS.TS Trần Huy Thịnh làm chủ nhiệm đề tài.

\section{TÀI LIỆ THAM KHẢO}

1. 900-world-fact-sheets.pdf. (n.d.). Retrieved from https:// gco.iarc.fr/today/ data/factsheets/ populations/ 900-world-fact-sheets.pdf

2. 704-viet-nam-fact-sheets.pdf.

(n.d.). Retrieved from https://gco.iarc.fr/ today/data/factsheets/ populations/ 704-viet-namfact-sheets.pdf
3. Hallmarks of cancer: the next generation. (2011). cell, (144), 646-674.

4. Tartour E, Zitvogel L. (n.d.). Lung cancer: potential targets for immunotherapy. Lancet Respir Med, (1), 551-563.

5. Braza, M. S., \& Klein, B. (2013). Anti-tumour immunotherapy with Vy9Vס2 T lymphocytes: from the bench to the bedside. British Journal of Haematology, 160(2), https://doi.org/10.1111/bjh.12090

6. Kobayashi, H., \& Tanaka, Y. (2015). үठ T Cell Immunotherapy-A Review. Pharmaceuticals, 8(1), 40-61. https://doi.org/10.3390/ph8010040

7. Chen, $X .$, Shang, W., Xu, R., Wu, M., Zhang, $X$. Huang, P., ... Pan, S. (2019). Distribution and functions of $y \delta T$ cells infiltrated in the ovarian cancer microenvironment. Journal of Translational Medicine, 17. https://doi.org/10.1186/s12967-019-1897-0

8. $y \delta T$ cell-mediated individualized immunotherapy for hepatocellular carcinoma considering clinicopathological characteristics and immunosuppressive factors. (n.d.). Retrieved 27 April 2021, from https://www.spandidospublications.com/10.3892/ol.2018.8026/abstract

9. E.S. Morrow, A. Roseweir, J. Edwards. (2019). The role of gamma delta $T$ lymphocytes in breast cancer: a review. Transl. Res, (203, pp.88-96).

10. Toia, F., Di Stefano, A. B., Meraviglia, S., Lo Presti, E., Pirrello, R., Rinaldi, G., ... Cordova, A. (2019). Г $\delta T$ Cell-Based Immunotherapy in Melanoma: State of the Art. Journal of Oncology, 2019. https://doi.org/10.1155/2019/9014607

\title{
KHẢO SÁT KẾT QUẢ CHİ Số ĐƯờ'NG HUYẾT VÀ HUYẾT ÁP Ở NGƯờI BÊ̂NH ĐÁI THÁO ĐƯờ'NG TYPE 2 CÓ TĂNG HUYẾT ÁP SAU 03 THÁNG ĐIỀU TRI NGOẠI TRÚ TẠI BỆNH VIỆN TRƯỜNG ĐẠI HỌC TRÀ VINH
}

\section{TÓM TẮT}

Nghiên cứu được thực hiện dựa trên 294 hồ sơ bệnh án của người bệnh được chẩn đoán đái tháo đường type 2 có tăng huyết áp đang điều trị ngoại trú tại Bệnh viện Trường Đại học Trà Vinh trong tháng 01/2020, theo dõi đến tháng 04/2020. Kết quả nghiên cứu cho thấy, tuổi trung bình của đối tượng nghiên cứu là 62,6 ( $\pm 9,4)$, đa số người bệnh ở lứa tuổi từ 50 trở lên (chiếm 92,5\%). Tỷ lệ người bệnh thuộc giới nữ $(70,1 \%)$ cao hơn so với giới nam $(29,9 \%)$. Nhóm thuốc điều trị đái tháo đường được sử dụng nhiều nhất là biguanid và sulfonylurea, cụ thể là metformin $(73,5 \%)$ và gliclazid $(81,1 \%)$. Nhóm thuốc điều trị

${ }^{1}$ Trường Đại học Trà Vinh.

²Bênh viện Đa khoa Hồng Đức

Chịu trách nhiệm chính: Trân Thị Thanh Tuyền

Email: thanhtuyen26435@gmail.com

Ngày nhận bài: 25.2.2021

Ngày phản biên khoa họ: 31.3.2021

Ngày duyệt bài: 12.4.2021

\section{Trần Thị Thanh Tuyền ${ }^{1}$, Nguyễn Bảo Ngọc ${ }^{2}$}

tăng huyết áp được sử dụng nhiều nhất là ức chế thụ thể $(65,5 \%)$ và chẹn kểnh calci $(44,2 \%)$. Kết quả kiểm soát đường huyết lúc đói và huyết áp dựa trên tiêu chuẩn của Bộ Y tế và Hiệp hội Đái tháo đường Hoa Kỳ (ADA 2021), có 47,8\% người bệnh đạt mục tiêu $F P G, 43,5 \%$ người bênh đạt mục tiểu huyết áp, trong đó có $24,2 \%$ người bệnh đạt cả 2 mục tiêu FPG và huyết áp. Kết quả này là cơ sở nhằm giúp bác sĩ đánh giá được hiệu quả kiểm soát các chỉ số xét nghiệm đường huyết và huyết áp, nâng cao chất lượng điều trị bệnh.

Tư khóa: đái tháo đường, tăng huyết áp, bệnh mãn tính.

\section{SUMMARY}

SURVEY RESULTS OF BLOOD SUGAR AND BLOOD PRESSURE IN PATIENTS WITH TYPE 2 DIABETES AND HYPERTENSION AFTER 03 MONTHS OF OUTPATIENT TREATMENT AT TRA VINH UNIVERSITY HOSPITAL

The study was executed based on 294 medical 
records of patients diagnosed with type 2 diabetes and hypertension who were outpatient treated at Tra Vinh University Hospital in January 2020 and kept track until April 2020. The study result shows that the average age of patients in study is $62.6( \pm 9.4)$ years, the age of patients is almost 50 and above (92.5\%). The proportion of patients who are female $(70.1 \%)$ is higher than that of men $(29.9 \%)$. The group of drugs are most used to treat diabetes are biquanide and sulfonylurea, especially metformin (73.5\%) and gliclazide $(81.1 \%)$. The group of drugs are most used to treat hypertension is ARBs $(65.5 \%)$ and CCB dihydropyridines (44.2\%). The results of controlling the fasting plasma glucose and blood pressure are based on the standards of the Ministry of Health and American Diabetes Association (ADA 2021), 47.8\% of patients get FPG goals, $43.5 \%$ of patients get blood pressure goals, of which $242 \%$ of patients achieve both FPG and blood pressure goals. This result is the basis for the physician to evaluate the effectiveness of controlling blood glucose and blood pressure test, improving the quality of treatment.

Keywords: diabetes, hypertension, chronic diseases

\section{I. ĐẶT VẤN ĐỀ}

Đái tháo đường (ĐTĐ) và tăng huyết áp (THA) là những vấn đề sức khỏe quan trọng đối với ngành y tế trên toàn thế giới. Nhiều nghiên cứu chứng minh rằng hai bệnh này thường kết hợp với nhau, đã mắc bệnh ĐiTĐ thì rất dễ bị THA và ngược lại. Tỷ lệ mắc THA ở người bệnh ĐTĐ type 2 tăng 2,5 lần so với người không bị ĐTĐ, khoảng $50 \%$ người bệnh ĐTÐ đồng thời bị THA. Nguy cơ tử vong tương đối tăng dần theo tuổi do biến cố tim mạch ở người mắc bệnh ĐTĐ type 2 cao gấp ba lần so với dân số nói chung. Sự hiện diện của THA ở người bệnh ĐTĐ làm tăng đáng kể nguy cơ mắc bệnh tim mạch vành, đột quy, bệnh thận và bệnh võng mạc [1]. Do đó, việc kiểm soát tốt đường huyết và huyết áp sẽ làm giảm tỷ lệ biến chứng, nâng cao chất lượng cuộc sống của người bệnh và cũng là mục tiêu chính trong công cuộc phòng và quản lý bểnh ĐTĐ.

Theo nghiên cứu về mô hình bệnh tật ở các cơ sở khám chữa bệnh tại tỉnh Trà Vinh trong những năm gần đây cho thấy, THA và ĐTĐ đang nằm trong danh sách 10 bệnh thường gặp và 10 bệnh có tỷ lệ mắc cao nhất trong nhóm bệnh không truyền nhiễm[2]. Bệnh viện Trường Đại Học Trà Vinh là bệnh viện mới thành lập, cơ số thuốc vẫn còn hạn chế và đang trong giai đoạn bổ sung, vì thế chưa được phong phú. Hiện bệnh viện đang điều trị hơn 300 người bệnh ĐTÐ có THA ngoại trú, nhưng chưa có nghiên cứu nào liên quan đến việc kiểm soát đường huyết và huyết áp trên đối tượng này. Xuất phát từ thực tế nêu trên, đề tài: "Khảo sát kêt quả chi số đường huyêt và huyêt áp ở người bệnh đái tháo đường type 2 có tăng huyêt áp sau 03 tháng điều trị ngoại trú tại Bệnh viện Trường Đại Học Trà Vinh"được thực hiện với 03 mục tiêu:

1. Mô tả đặc điểm về tuổi và giới của mẫu nghiên cứu.

2. Khảo sát tỷ lệ sử dụng các nhóm thuốc để kiểm soát đường huyêt và huyêt áp.

3. Khảo sát kết quả chi số đường huyêt và huyết áp sau 03 tháng điều trị bằng thuốc.

\section{II. ĐỐI TƯợNG VÀ PHƯƠNG PHÁP NGHIÊN CỨU 2.1 Đối tượng nghiên cứu \\ Tiêu chuân chọn mẫu: Hồ sơ bênh án điện} tử của người bệnh ngoại trú có chẩn đoán đái tháo đường type 2 và tăng huyết áp được chỉ định điêu trị bằng thuốc.

Tiêu chuẩn loại trừ:

+ Hồ sơ bệnh án của người bệnh dưới 18 tuổi.

+ Hồ sơ bệnh án của người bệnh là phụ nữ có thai.

+ Hồ sơ bệnh án không có chỉ định các xét nghiệm cận lậm sàng.

+ Hồ sơ bệnh án được chỉ định các xét nghiệm cận lâm sàng nhưng người bệnh không tuân thủ.

\subsection{Phương pháp nghiên cứu}

Thiết kế nghiên cứu: Nghiên cứu tiến cứu mô tả dựa trên thông tin thu thập từ hồ sơ bệnh án điện tử của người bệnh ngoại trú.

Phương pháp thu mẫu: Trong 01 tháng đầu nghiên cứu, chọn tất cả hồ sơ bệnh án điện tử của người bệnh được chẩn đoán đái tháo đường type 2 và tắng huyết áp thỏa tiêu chuẩn chọn mẫu. Từ hồ sơ bệnh án, thu thập thông tin cần thiết để nghiên cứu và theo dõi các bệnh án này qua những đợt điều trị tiếp theo trong 03 tháng, để đánh giá mục tiêu kiểm soát đường huyết và huyết áp. Với quy ước: $T_{0}$ là thời điểm bắt đầu nghiên cứu trên đối tượng người bệnh cụ thể. $T_{1}, T_{2}, T_{3}$ là thời điểm sau khi bắt đầu nghiên cứu lần lượt 1, 2, 3 tháng.

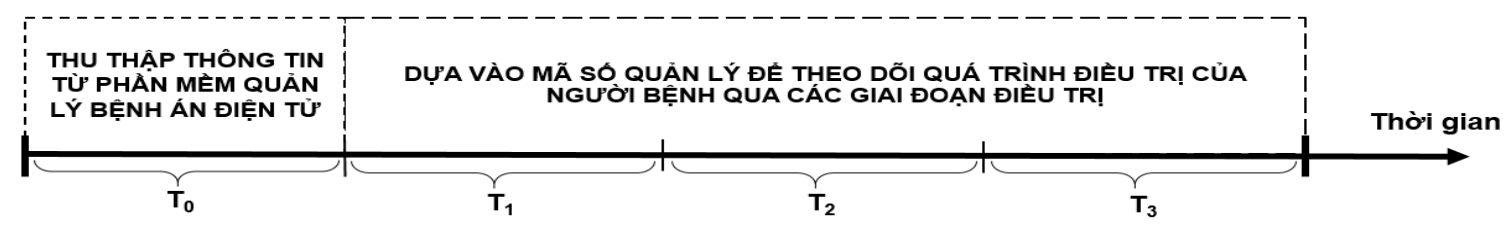

Hình 1. Sơ đồ theo dôi người bệnh qua các thời điểm 
Xử lý số liệu: Số liệu được nhập và xử lý bằng phần mềm Microsoft Excel, thống kê bằng phần mềm SPSS 25.0. Tra cứu tương tác thuốc bằng Công cụ kiểm tra giám sát an toàn đơn thuốc trên trang thongtinthuoc.com. Phân loại mức độ kiểm soát đường huyết và huyết áp dựa vào hướng dẫn mới nhất của Bộ Y tế và khuyến cáo của Hiệp hội đái tháo đường Hoa Kỳ (ADA 2021).

\section{KẾT QUẢ NGHIÊN CỨU}

\section{1. Đặc điểm về tuổi và giới}

Bảng 1. Phân bốngười bệnh theo nhóm tuổi

\begin{tabular}{|c|c|c|}
\hline Nhóm tuổi & $\begin{array}{c}\text { Lượt người } \\
\text { bệnh }\end{array}$ & $\begin{array}{c}\text { Tỷ lệ } \\
(\mathbf{\%})\end{array}$ \\
\hline$<40$ & 5 & 1,7 \\
\hline 40 đến $\leq 49$ & 17 & 5,8 \\
\hline 50 đến $\leq 59$ & 85 & 28,9 \\
\hline 60 đến $\leq 69$ & 123 & 41,8 \\
\hline$\geq 70$ & 64 & 21,8 \\
\hline Tổng & 294 & 100 \\
\hline \multicolumn{2}{|c|}{ Tuổi trung bình } & \multicolumn{2}{|c|}{$62,6 \pm 9,4$ tuổi } \\
\hline
\end{tabular}

Trong số 294 hồ sơ bệnh án của người bệnh ĐTÐ type 2 có THA được chọn vào mấu nghiên cứu, nhóm tuổi 60 đến $\leq 69$ chiếm tỷ lệ cao nhất là $41,8 \%$. Nhóm tuổi thấp nhất là <40 tuổi, chiếm tỷ lệ $1,7 \%$. Tiếp theo là nhóm tuổi từ 40 đến $\leq 49$ chiếm tỷ lệ $5,8 \%$. Tuổi trung bình của đối tượng nghiên cứu là $62,6( \pm 9,4)$ năm, ít tuổi nhất là 35 tuổi và cao nhất là 89 tuối.

Nghiên cứu về sự phân bố giới tính của người bệnh trong mẫu được trình bày ở hình 2 .

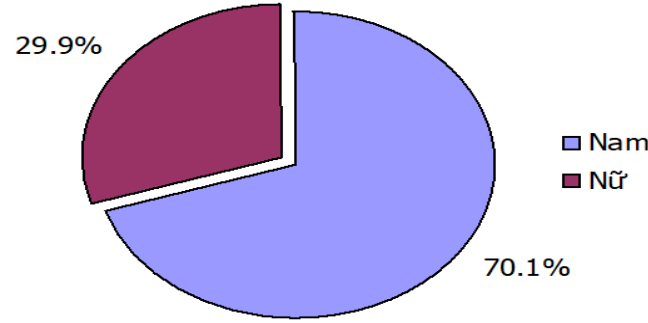

Hình 2. Phân bố người bệnh theo giới tính Người bệnh thuộc giới nữ là 206 người chiếm tỷ lệ $70,1 \%$, vượt trội so với giới nam là 88 người (29,9\%).

3.2 Kết quả khảo sát tỷ lệ sử dụng thuốc để kiểm soát đường huyết và huyểt áp

Hai bệnh ĐTÐ và THA là bệnh mãn tính, gân như phải sử dụng thuốc suốt đời. Hiện nay, có nhiều nhóm thuốc cũng như hoạt chất điều trị, nghiên cứu thông kê tỷ lệ các thuốc sử dụng trong 03 tháng điều trị được trình bày trong bảng 2 và bảng 3 .

Bảng 2. Tỷ lệ sử dụng thuốc điều trị đái tháo đường

\begin{tabular}{|c|c|c|c|}
\hline Nhóm thuốc & Hoạt chất & $\begin{array}{c}\text { Lượt sử } \\
\text { dụng }\end{array}$ & $\begin{array}{c}\text { Tỷ lệ } \\
\text { (\%) }\end{array}$ \\
\hline Biguanid & Metformin & 611 & 73,5 \\
\hline \multirow{2}{*}{ Sulfonylurea } & Gliclazid & 674 & 81,1 \\
\cline { 2 - 4 } & Glibenclamid & 20 & 2,4 \\
\cline { 2 - 4 } & Glimepirid & 59 & 7,1 \\
\hline \multirow{2}{*}{$\begin{array}{c}\text { Úc chế alpha } \\
\text { - glucosidase }\end{array}$} & Acarbose & 9 & 1,1 \\
\hline Insulin & Insulin & 18 & 2,2 \\
\hline
\end{tabular}

Trong cả 03 thời điểm nghiên cứu, người bênh chủ yếu được điều trị ĐTĐ bằng 02 nhóm thuốc là biguanid và sulfonylurea, cụ thể là metformin với $73,5 \%$ người bệnh sử dụng và gliclazid với $81,1 \%$ người bênh sử dụng. Lượt người bệnh được chỉ định acarbose và insulin thấp $(1,1 \%$ và $2,2 \%)$.

Bảng 3. Tý lệ sử dụng thuốc điều trị tăng huyêt áp

\begin{tabular}{|c|c|c|c|}
\hline $\begin{array}{l}\text { Nhóm } \\
\text { thuốc }\end{array}$ & Hoạt chất & $\begin{array}{l}\text { Lượt sử } \\
\text { dụng }\end{array}$ & $\begin{array}{l}\text { Tỷ lệ } \\
(\%)\end{array}$ \\
\hline \multirow{2}{*}{ Lợi tiểu } & Hydrochlorothiazid & 216 & 26,0 \\
\hline & \begin{tabular}{|l} 
Spiron \\
\end{tabular} & 5 & 0,6 \\
\hline \multirow{3}{*}{$\begin{array}{l}\text { Chẹn kênh } \\
\text { calci }\end{array}$} & & 360 & 43,3 \\
\hline & & 7 & 0,8 \\
\hline & $n$ & 1 & 0,1 \\
\hline \multirow{3}{*}{$\begin{array}{l}\text { Ức chế } \\
\text { men chuyển }\end{array}$} & Capt & 7 & 0,8 \\
\hline & & 93 & 11,2 \\
\hline & & 5 & 0,6 \\
\hline \multirow{4}{*}{$\begin{array}{l}\text { Ức chế thụ } \\
\text { thể } \\
\text { Angiotensin } \\
\text { II }\end{array}$} & & 408 & 49,1 \\
\hline & & 2 & 0,2 \\
\hline & & 72 & 8,7 \\
\hline & Telm & 62 & 7,5 \\
\hline \multirow{4}{*}{$\begin{array}{l}\text { Chẹn Beta } \\
\text { chọn lọc }\end{array}$} & eno & 3 & 0,4 \\
\hline & 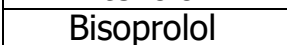 & 106 & 12,8 \\
\hline & & 5 & 0,6 \\
\hline & Nebivolol & 15 & 1,8 \\
\hline
\end{tabular}

Ức chế thu thể và chen kênh calci là 2 nhóm thuốc được chỉ định nhiều nhất, chiếm tỷ lệ $65,5 \%$ và $44,2 \%$. Nhóm thuốc lợi tiểu đều được sử dụng dưới dạng phối hợp với nhóm thuốc khác, chiếm tỷ lể $26,6 \%$. Nhóm thuốc được sử dụng ít nhất là ức chế men chuyển $(12,6 \%)$.

Trong nghiên cứu này, đối tượng là người bênh ĐTĐ type 2 có THA nên sử dụng tương đối nhiều thuốc vì vậy rất dễ xảy ra tương tác thuốc trong đơn. Tra cứu đơn thuốc bằng Công cụ kiểm tra giám sát an toàn đơn thuốc trên trang Thongtinthuoc.com, trong tổng số 831 đơn thuốc nghiên cứu, có 365 đơn thuốc có xảy ra tương tác chiếm tỷ lệ 43,9\%. Tương tác chỉ ở mức độ nhe, vừa phải và nặng, không phát hiện cặp tương tác mức độ chống chỉ định. Tỷ lệ xuẩt hiện tương tác thuốc ở các đơn thuốc theo sự phân bố số thuốc trong đơn được trình bày ở bảng 4. 
Bảng 4. Kêt quả tỷ lệ tương tác thuốc theo sự phân bố số thuốc trong đơn

\begin{tabular}{|c|c|c|c|}
\hline $\begin{array}{c}\text { Số } \\
\text { thuốc/đơn }\end{array}$ & Số đơn & $\begin{array}{c}\text { Số đơn có } \\
\text { tương tác }\end{array}$ & $\begin{array}{c}\text { Tỷ lệ } \\
(\mathbf{\%})\end{array}$ \\
\hline $\mathbf{0 1 - 0 4}$ & 472 & 126 & 26,7 \\
\hline $\mathbf{0 5}-\mathbf{0 7}$ & 345 & 228 & 66,1 \\
\hline $\mathbf{0 8 - 1 0}$ & 14 & 11 & 78,6 \\
\hline
\end{tabular}

3.3 Kết quả kiểm soát chỉ số đường huyết và huyết áp. Tại thời điểm $T_{3}$ có 161 người bệnh có đầy đủ dữ liệu về chỉ số đường huyết lúc đói (FPG) và chỉ số huyết áp, nghiên cứu dựa vào bệnh án của những người bệnh này để khảo sát kết quả kiểm soát các chỉ số đường huyết và huyết áp sau 03 tháng nghiên cứu. Căn cứ vào mục tiêu điều trị theo hướng dẫn của $A D A$ và Bộ $Y$ tế, thống kê kết quả về mức độ kiểm soát đường huyết và huyết áp trong bảng 5 và bảng 6 .

Bảng 5. Kêt quả kiểm soát từng chỉ số FPG và huyêt áp

\begin{tabular}{|c|c|c|c|c|}
\hline \multirow{2}{*}{$\begin{array}{l}\text { Mứcc độ } \\
\text { kiểm } \\
\text { soát }\end{array}$} & \multicolumn{2}{|c|}{ FPG } & \multicolumn{2}{|c|}{ Huyết áp } \\
\hline & $\begin{array}{l}\text { Lượt } \\
\text { người } \\
\text { bệnh }\end{array}$ & $\begin{array}{l}\text { Tỷ lệ } \\
(\%)\end{array}$ & $\begin{array}{l}\text { Lượt } \\
\text { người } \\
\text { bệnh }\end{array}$ & $\begin{array}{l}\text { Tỷ lệ } \\
\text { (\%) }\end{array}$ \\
\hline Đạt & 77 & 47,8 & 70 & 43,5 \\
\hline Chưa đạt & 84 & 52,2 & 91 & 56,5 \\
\hline Tống & 161 & 100,0 & 161 & 100,0 \\
\hline
\end{tabular}

Số người bệnh đạt mục tiêu về chỉ số FPG là 77 người chiếm $47,8 \%$ và số người bênh đạt mục tiêu về huyết áp là 70 người chiếm $43,5 \%$.

Bảng 6. Kết quả kiểm soát cả 02 chỉ số FPG và huyết áp

\begin{tabular}{|c|c|c|}
\hline $\begin{array}{c}\text { Mức độ } \\
\text { kiểm soát }\end{array}$ & \multicolumn{2}{|c|}{ FPG và Huyết áp } \\
\cline { 2 - 3 } & Lượt người bệnh & Tỷ lệ (\%) \\
\hline Đạt & 39 & 24,2 \\
\hline Chưa đạt & 53 & 32,9 \\
\hline Tống & $\mathbf{9 2}$ & $\mathbf{5 7 , 1}$ \\
\hline
\end{tabular}

Trong tổng số 161 người bênh có đây đủ dữ liệu về chỉ số FPG và chỉ số huyết áp ở thời điểm $T_{3}$, số người đạt mục tiêu cả 02 chỉ số FPG và huyết áp là 39 người chiếm $24,2 \%$ và chưa đạt cả 02 mục tiêu chiếm 32,9\%.

\section{BÀN LUÂ̂N}

4.1 Đặc điểm về tuổi và giới. Tuổi trung bình trong mẫu nghiên cứu là $62,6( \pm 9,4)$ năm là độ tuổi được xếp vào lớp tuổi già theo WHO, kết quả này tương đồng với nghiên cứu của Chung Bá Ngọc và cộng sự tại bệnh viện Nhân Dân Gia Định với tuổi trung bình là 62,81 ( \pm $11,437)$ năm [4]. Nhóm tuổi từ 50 đến 69 chiếm tỷ lệ cao nhất $(70,7 \%)$ và thấp nhất là nhóm tuổi dưới 40 tuổi $(1,7 \%)$. Kết quả này cho thây người bệnh ĐTĐ type 2 có THA ở độ tuổi từ 50 trở lên chiếm tỷ lệ rất cao, còn nhóm tuổi dưới 40 thì có tỷ lệ thấp hơn. Kết quả này giống với nghiên cứu của Trần Văn Trung tại Bệnh viện Đa Khoa tỉnh Hà Tĩnh với tỷ lệ người bệnh trền 50 tuổi chiếm 97,75\% [5]. Như vậy người bệnh ĐTĐ type 2 có THA đa số là người trung niên và cao tuổi.

Về tỷ lệ giới tính, người bệnh là nữ giới chiếm tỷ lệ $70,1 \%$ vượt trội so với nam giới $(29,9 \%)$. Kết quả này cũng tương tự với nghiên cứu của Đoàn Thị Thu Hương tại Bệnh viện $Y$ học cổ truyền Bộ Công An (2015), với tỷ lệ nữ là 69,32\% và nam là $30,68 \%$ [7]. Kết quả nghiên cứu có sự khác biệt với nghiên cứu của Trần Văn Trung với tỷ lệ giới tính gần tương đương nhau (nam chiếm $51,69 \%$, nữ chiếm 48,31\%)[5]. Nguyên nhân có thể do sự khác nhau về phương pháp lựa chọn đối tượng nghiên cứu và khu vực địa lý.

4.2 Kết quả khảo sát tỷ iệ sử dụng thuốc để kiểm soát đường huyết và huyết áp. Tại Bênh viên Trường Đại hoc Trà Vinh hiên có 4 nhóm thuốc được sử dụng điều trị ĐTĐ là biguanid (metformin), sulfonylure (gliclazid, glibenclamid, glimepirid), acarbose và insulin. Trong đó người bệnh chủ yếu được chỉ định sử dụng nhóm thuốc biguanid và sulfonylurea, chỉ định sử dụng acarbose và insulin chiếm tỳ lệ thấp. Theo $\mathrm{ADA}$ nên phối hợp metformin với các nhóm sulfonylurea, thiazolidinedion (TZD), ức chế kênh đồng vận chuyển natri - glucose (SGLT-2i), ức chế enzym DPP-4, đồng vận thụ thể GLP-1, insulin trong trị liệu kép và trị liệu ba để tăng hiệu quả điều trị. Có thể thây ở Bệnh viện Trường Đại học Trà Vinh chưa có nhiều lựa chọn thuốc để phối hợp, vì đây là bệnh viện hang 3 nên cơ số thuốc còn hạn chế. Metformin có lượt sử dụng tương đối cao $(73,5 \%)$ và có mặt trong hầu hết các đơn có phối hợp thuốc điểu trị ĐTĐ. Theo hướng dẫn của Bộ $Y$ tế và ADA thì tất cả người bệnh ĐTĐ được chỉ định sử dụng metformin trừ trường hợp chống chỉ định, vì vậy tỷ lệ sử dụng metformin trong nghiên cứu này chưa thực sự phù hợp so với hướng dẫn.

Theo khuyến cáo về kiểm soát THA ở người bệnh ĐTĐ của ADA, nhóm ức chế men chuyển, ức chế thụ thể, lợi tiểu và chen kênh calci là các nhóm thuốc được khuyên dùng. Trong nghiên cứu, nhóm ức chế thụ thể và chẹn kênh calci được chỉ định nhiều nhất $(65,5 \%$ và $44,2 \%)$, nhóm chẹn beta được sử dung ít $(15,6 \%)$ là phù hợp với hướng dẫn. Nhóm ức chế men chuyển là một trong những nhóm thuốc được khuyên dùng nhưng lại có chỉ định sử dụng ít nhất, chỉ từ $12,6 \%$. Kết quả này có sự khác biệt so với nghiên cứu của Trần Văn Trung với tỷ lệ ức chế men chuyển là $47,55 \%$ [5] và nghiên cứu của 
Trần Thiên Thanh tại Bệnh viên Đa Khoa Quảng Trị với tỷ lệ ức chế men chuyển $43,8 \%$, nguyên nhân do đối tượng trong nghiên cứu này đa số là người trung niền và người cao tuổi, nên bác sĩ chỉ định nhóm ức chế thụ thể thay cho ức chế men chuyển để giảm tác dụng phụ gây ho khan.

Về tương tác thuốc trong đơn, tương tác thuốc xuất hiên nhiều ở các đơn chứa nhiều thuốc, cụ thể ở những đơn có chỉ định $08-10$ thuốc, tỷ lể có tương tác thuốc lên đến $78,6 \%$, còn đối với các đơn có $01-04$ thuốc, thì tỳ lê tương tác thuốc xuất hiện chỉ có $26,7 \%$. Do đó, kiểm soát việc kê đơn để hạn chế số thuốc trong đơn cũng có thể làm giảm số tương tác thuốc xuất hiện.

4.3 Kết quả kiểm soát chỉ số đường huyết và huyết áp. Tăng glucose máu là nguyên nhân chính dần đến các biến chứng mạn tính của ĐTÐ, đặc biệt là các biến chứng về mạch máu. Viếc kiểm soát chăt chẽ chỉ số đường huyết và huyết áp giúp cải thiện rõ rệt sự tiến triển của các biến chứng. Theo khuyến cáo của ADA tập trung vào cá thể hóa điều trị cho người bệnh, đặc biệt là người bệnh ĐTÐ type 2 có THA. Sau 03 tháng nghiên cứu thì tỳ lệ người bệnh đạt các mục tiêu đều tăng lên so với trước, tỷ lệ người bệnh đạt đường huyết mục tiêu là $47,8 \%$, tỷ lệ này tương đương với nghiên cứu của Nguyễn Thị Nga $(47,8 \%)$ [9] và thấp hơn so với nghiên cứu của Nguyễn Thị Hồng Loan tại bênh viện y học Tuệ Tĩnh $(58,21 \%)$ [3]. Sự khác biêt này có thể do đối tượng nghiên cứu khác nhau, sự hiểu biết và tuân thủ điều trị cũng khác nhau, một số người bệnh được chỉ định thuốc ĐTÐ chưa phù hợp cũng có thể dẫn đến thất bại trong điều trị. Về mục tiêu huyết áp, chỉ có 43,5\% người bệnh đạt huyết áp mục tiêu, kết quả này thấp hơn nghiên cứu của Trần Văn Trung với tỷ lệ người bệnh đạt huyết áp mục tiêu khi ra viện là $66,29 \%$ [5] và nghiên cứu của Trần Thiện Thanh $(83,53 \%)$. Nguyên nhân do đối tượng trong nghiên cứu là người bệnh ngoại trú, nền việc tuân thủ điều trị không có sự giám sát chặt chẽ của điều dưỡng và bác sĩ, cũng có thể do chế độ thuốc điều trị khác nhau. Đối tượng trong nghiên cứu là người bênh ĐTĐ type 2 có THA nên việc điều trị cũng khó khăn hơn nhiều so với người chỉ mắc ĐTÐ hoặc THA, số lượng thuốc trong đơn nhiều dẫn đến xuất hiện nhiều tương tác trong đơn cũng ảnh hưởng đến hiêu quả điêu tri. Vì vâyy sau 03 tháng điều tri, có 24,2\% số người bệnh đạt cả 02 mục tiêu về FPG và huyết áp theo tiêu chí của khuyến cáo, tăng $14,9 \%$ so với To, tỷ lệ này khá cao. Số người bênh chưa đạt về cả 02 mục tiêu điêu trị sau 03 tháng nghiên cứu vẫn còn chiếm tỷ lệ cao (32,9\%), tuy nhiên đã giảm 7,5\% so với thời điểm To.

\section{KẾT LUÂ̂N}

Trong 294 người bệnh ĐTĐ type 2 có THA đang điều trị ngoại trú tại Bệnh viện Trường Đại học Trà Vinh, đa số người bệnh ở lứa tuổi từ 50 trở lên (chiếm 92,5\%), tỷ lệ người bệnh thuộc giới nữ cao hơn giới nam (nữ chiếm 70,1\%, nam chiếm 29,9\%). Biguanid và sulfonylurea là nhóm thuốc điều trị ĐTÐ được sử dụng nhiều nhất, cụ thể là metformin $(73,5 \%)$ và gliclazid $(81,1 \%)$. Nhóm thuốc điều tri tăng huyết áp được sử dung nhiều nhất là ức chế thụ thể $(65,5 \%)$ và chẹn kênh calci $(44,2 \%)$. Về kết quả chỉ số đường huyết và huyết áp, có $47,8 \%$ người bệnh đạt mục tiêu FPG, 43,5\% người bệnh đạt mục tiêu huyết áp, trong đó có $24,2 \%$ người bệnh đạt cả 2 mục tiêu FPG và huyết áp. Đề xuất tiếp tục thực hiện các nghiên cứu về sự tuân thủ sử dụng thuốc, tuân thủ chế độ vận động và chế độ ăn để đánh giá toàn diện hơon về kết quả điều trị.

\section{TÀI LIẸU THAM KHẢO}

1. Sowers J R. and et al. Diabetes, hypertension, and cardiovascular disease: an update. Hypertension. 2001; 4:1,053-1,059.

2. Nguyễn Thi Nhât Tảo và công sự. Khảo Sát Mô Hinh Bệnh Tật Tại Phòng Khám Đă Khoa Trường Đại Học Trà Vinh. Tap Chí Khoa Học Trường Đại Học Trà Vinh. 2018; 31:58 - 64.

3. Nguyễn Thị Hồng Loan. Thực trạng kiểm soát Glucose máu ở bênh nhân đái tháo đường type 2 điều trị ngoại trú tại bệnh viện Tuệ Tĩnh. Tap chí y hoc Viêt Nam. 2019; 1:135-139.

4. Chung Bá Ngọc và cộng sự. Tỉ lệ đại huyết áp mục tiêu trên bênh nhẩn đái tháo đường. Tạp chí Y hoc TP. Hồ Chí Minh. 2013; 6:13-18.

5. Trân Văn Trung. Khảo sát tình hình sử dụng thuốc trong điều trị tăng huyết áp ở bênh nhân đái tháo đường tại khoa nội tiết Bệnh viện Đa khoa tỉnh Hà Tînh. ['Luận văn Dược sĩ Chuyển Khoa cấp I]. Trường Đại học Dược Hà Nội; 2014.

6. Cao Mỹ Phượng và cộng sự. Nghiên cứu tỷ lê tăng huyết áp và liên quan với một số yếu tố nguy cơ ở người tư 40 tuổi trở lên tai tỉnh Trà Vinh năm 2012. Tap chí tim mach hoc Viết Nam. 2013; 65.

7. Đoàn Thị Thu Hướng. Phân tích thực trạng sử dụng thuốc trên bệnh nhân tăng huyết áp mắc kèm đái tháo đường tai phòng khám ngoại trú bệnh viện $\mathrm{Y}$ học cổ truyền Bộ Công an. [Luận văn Thạc sĩ Dược học], Trường Đại học Dược Hà Nội; 2015.

8. Đào Mai Hương. Nhân xét việc sử dụng thuốc điều trị Đái tháo đường dạng uống tại khoa khám bệnh Bệnh viện Bạch Mai. [Luận văn thạc sĩ dược học]. Trường Đai học Dước Hà Nôii; 2012.

9. Nguyễn Thị Nga. Nghiển cứu tình hình sử dung thuốc điều trị đái tháo đường type 2 của bệnh nhân điều trị ngoại trú tại Bệnh viện đa khoa Hà Đông. [Luân văn tốt nghiêp dược sĩ chuyên khoa cấp I]. Trường Đại học Dược Hà Nội; 2011. 